BIS

WORKING PAPERS No. 43

\title{
EXCHANGE RATE REGIMES AND THE EXPECTATIONS HYPOTHESIS OF THE TERM STRUCTURE
}

by

Stefan Gerlach and Frank Smets

July 1997

BANK FOR INTERNATIONAL SETTLEMENTS

Monetary and Economic Department

BASLE 
BIS Working Papers are written by members of the Monetary and Economic Department of the Bank for International Settlements, and from time to time by outside economists, and are published by the Bank. The papers are on subjects of topical interest and are technical in character. The views expressed in them are those of their authors and not necessarily the views of the BIS.

(C) Bank for International Settlements 1997

CH-4002 Basle, Switzerland

Also available on the BIS World Wide Web site (http://www.bis.org).

All rights reserved. Brief excerpts may be reproduced or translated provided the source is stated. 


\title{
EXCHANGE RATE REGIMES AND THE EXPECTATIONS HYPOTHESIS OF THE TERM STRUCTURE*
}

\author{
by \\ Stefan Gerlach and Frank Smets
}

July 1997

\begin{abstract}
This paper uses weekly data on short-term eurorates for ten countries for the period 1979-96 to document that the ability of the expectations hypothesis (EH) to account for movements in the term structure is greater, and that short-term interest rates are more predictable, under fixed than under floating exchange rates. The paper also shows that the higher predictability does not arise solely because of monetary policy responses to speculative pressures in the foreign exchange markets: while it is more difficult to reject the EH in periods of exchange market turmoil, the EH is not rejected in tranquil periods.
\end{abstract}

Key words: Term structure of interest rates, expectations hypothesis, speculative attacks. JEL classification: E4.

The views expressed in this paper are solely our own and do not necessarily reflect those of the BIS. This paper was written in response to the comments we received on the paper we presented at the conference (Gerlach and Smets, 1997). We are grateful to our discussant, Gikas Hardouvelis and conference participants for discussions, and to Ignazio Angeloni, Gabriele Galati, Greg Sutton and Kostas Tsatsaronis for comments on this and our earlier paper. Florence Béranger provided excellent research assistance. 



\section{Contents}

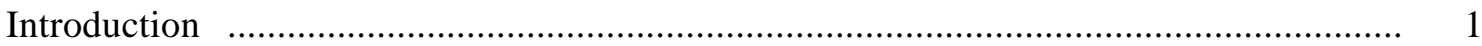

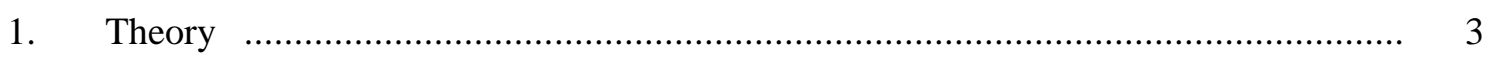

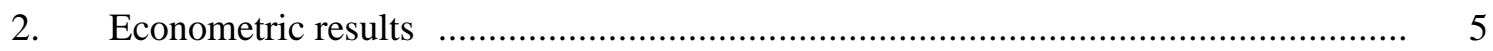

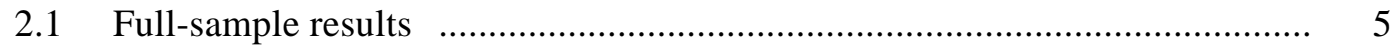

2.2 The EH, exchange rate regimes and the predictability of future short rates $\ldots . . .9$

3. The EH and exchange market turmoil …........................................................... 13

3.1 Change in interest rate spreads ........................................................... 13

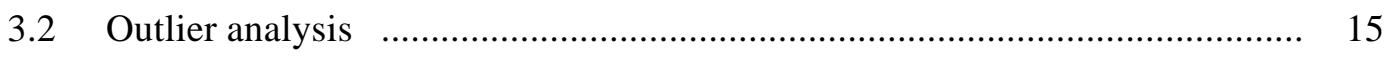

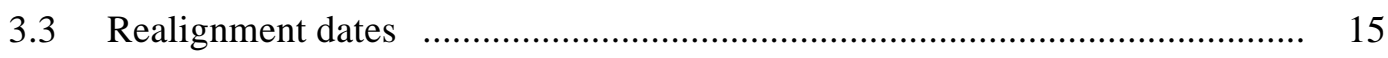

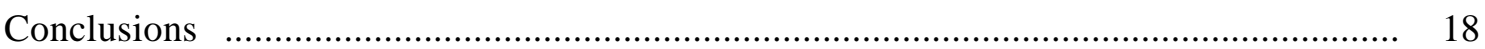

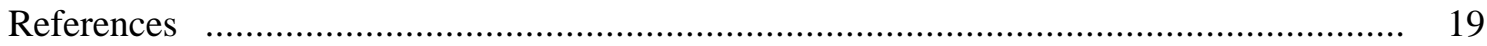





\section{Introduction}

The term structure of interest rates plays an important role in much of modern financial economics and in the design of monetary policy. Unfortunately, the standard conclusion in the existing empirical literature on the term structure is that current theoretical models do not explain movements in short and long interest rates. Shiller (1990, p. 670), for instance, in surveying the term structure argues that: "Empirical work on the term structure has produced consensus on little more than that the rational expectations model ... can be rejected."

More recently, however, several authors have noted that the explanatory power of the expectations hypothesis $(\mathrm{EH})$ of the term structure - which states that longer interest rates are averages of expected future short interest rates plus, perhaps, a constant term premium - tends to be greater outside the United States. For example, Hardouvelis (1994), studying the behaviour of three-month and ten-year rates in the Group of Seven (G-7) countries, finds that the EH appears to do a particularly poor job of accounting for the behaviour of interest rates in the United States, but that it works quite well in other countries. ${ }^{1}$ Further evidence suggesting that it is more difficult to reject the EH using non-US data is provided by Gerlach and Smets (1997), who use 1, 3, 6 and 12-month eurorates in 17 countries to show that, while they are unable to reject the EH in a majority of cases, for the United States the EH can be rejected for all maturities. Kugler $(1988,1990)$ also finds that the EH does a much better job of explaining the short end of the term structure of interest rates in Switzerland and Germany than in the United States.

One possible reason why it is more difficult to reject the EH outside the United States is that short-term interest rates may be easier to predict in other countries. Mankiw and Miron (1986) show that in the presence of a time-varying term premium, differences in the predictability of short-term interest rates can have a large impact on tests of the EH. Gerlach and Smets (1997) use a simple forecasting model to estimate the predictability of short-term rates for the 17 currencies they study, and demonstrate that tests of the EH fare better in countries in which short-term rates are more forecastable, as hypothesised by Mankiw and Miron (1986). This raises the question of why the predictability varies between countries.

The point of departure for this paper is the suggestion in Gerlach and Smets (1997) that the higher predictability of short-term rates in some European countries may be due to the fact that these countries operated with adjustable peg regimes during a large part of the sample periods used

1 In related work, Gerlach (1996) studies short and long interest rates in 14 countries, and finds large differences between countries in the ability of the expectations hypothesis to account for movements in the term structure. 
and that they experienced episodes of speculative pressures in the foreign exchange market. ${ }^{2}$ Since central banks typically respond to such pressures by raising short-term interest rates to very high levels for a brief period, after which they reduce them to more normal levels, the combination of such pressures and systematic policy responses renders short-term rates relatively predictable. That speculative attacks could be important for tests of the EH is suggested by the work of Jondeau and Ricart (1996), who, using data on French franc interest rates, show that tests of the EH are sensitive to the inclusion of a few observations that are related to episodes of exchange market turmoil. While the EH is accepted for the 12 pairs of maturities they study when the whole sample is used, only for five of these do they accept the EH when observations associated with speculative attacks in 1981 and 1983 are removed. Considerable instability of term structure regressions is also documented by Dahlquist and Jonsson (1995), who study the short end of the term structure of Swedish Treasury bills. In particular, it appears that the expectations hypothesis can be rejected for periods in which foreign exchange markets were calm.

The purpose of this paper is twofold: first, to see whether the EH is rejected less frequently in countries in which central banks conduct policy using intermediate exchange rate targets than in countries where no such targets are employed; and secondly, if this is the case, to assess whether this is due to occasional episodes of exchange market turmoil. To do so, we use weekly data on 1, 3, 6 and 12-month euro-interest rates from ten countries. So as to clearly distinguish between fixed and flexible exchange rate regimes the data start after the establishment of the ERM in 1979 and end in $1996 .{ }^{3}$

In order to assess the importance of the exchange rate regime, we informally distinguish between countries operating with and without intermediate exchange rate targets. The group of countries without intermediate exchange rate objectives consists of the United States, Japan, Germany, Canada and the United Kingdom. The comparison group of countries with intermediate exchange rate targets comprises Belgium, France, Italy, the Netherlands and Sweden. This selection of countries warrants several comments. Although Germany has been an ERM member since the system was founded in 1979, it has not faced the same exchange rate constraint as the other members by virtue of the fact that it has been the de facto anchor country. Moreover, some countries changed this exchange rate regime during the estimation period. The United Kingdom was a member of the ERM between October 1990 and September 1992. Italy belonged to the ERM until September 1992. While Sweden has never participated in the ERM, between 1977 and 1991 Swedish monetary policy was geared to an intermediate exchange rate expressed in terms of a trade-weighted basket in which the core ERM currencies played an important role, and in 1991-92 a unilateral ECU peg was used. Since

2 Kugler $(1988,1990)$ argues that short-term interest rates have been more predictable in Switzerland and Germany because the authorities have conducted monetary policy using money stock targeting, while the Federal Reserve has tended to smooth interest rates.

3 Gerlach and Smets (1997) used all available data to test the expectations hypothesis, and thus disregarded the fact that the exchange rate regime may have changed in the estimation period. 
November 1992, however, the krona has been floating. Despite these changes in the operating framework in the United Kingdom, Italy and Sweden, we use the same sample period for all countries since preliminary empirical work indicates that shortening the sample period to 1979-90 for the United Kingdom and 1979-92 for Italy and Sweden has virtually no effect on the estimated parameters.

To distinguish between periods of tranquillity and turbulence in the foreign exchange market we use three different criteria. The first of these is based on the behaviour of the spread of domestic interest rates over foreign interest rates. Speculative pressures on the domestic currency are typically associated with sharp but temporary increases in the spread between domestic and foreign interest rates. We thus define a speculative attack episode as the week in which the spread between domestic and foreign interest rates increases substantially plus the immediately following weeks. The second criterion is purely statistical: we drop observations for which the residual is more than two standard deviations large in absolute value. Finally, we define as turbulent episodes the periods around ERM realignments involving the French franc and Italian lira. ${ }^{4}$

Overall, the results are not very sensitive to the criterion we use to divide the sample into calm and turbulent periods. In general, we find that the $\mathrm{EH}$ fits the data better in periods of speculative pressures in the exchange market. However, we are typically not able to reject the EH in the calmer periods. Thus, we do not believe that speculative attacks are the sole reason why it tends to be more difficult to reject the $\mathrm{EH}$ in data for countries where monetary policy is conducted using intermediate exchange rate objectives.

The remainder of this paper is organised as follows. In Section 1 we use the expectations theory to derive the equation that we estimate to test the EH. The theory implies that the realised future excess return on rolling over a one-period investment over j periods should be related on a oneto-one basis to the current spread between j-period and one-period interest rates. Section 2 reports the estimates of the equation, and shows that the EH does indeed fare better in countries conducting monetary policy using fixed exchange rates. Section 3 goes on to see whether this is due to the occurrence of occasional speculative attacks, but finds that this is not the case. Finally, the last section contains some conclusions.

\section{Theory}

In order to test the EH we follow Hardouvelis (1994) and Gerlach and Smets (1997), among others, and perform multiperiod regressions. The theoretical underpinning for these regressions is straightforward. Let $\mathrm{R}_{t}^{(\mathrm{j})}$ denote the j-month interest rate at time $t, \theta_{t}^{(j)}$ a possible non-zero but

4 The reason for focusing on France and Italy is that, among the countries studied here, they have been involved in a relatively large number of parity changes. 
constant $\mathrm{j}$-month term premium and $\mathrm{E}_{\mathrm{t}} \mathrm{r}_{\mathrm{t}+\mathrm{k}}$ the expected value of the one-month interest rate at time $\mathrm{t}+\mathrm{k}$, formed on the basis of information available at time $\mathrm{t}$. All interest rates are expressed at annualised rates. In what follows, we use 3, 6 and 12-month rates, so that $\mathrm{j}=3,6$ and 12. In the econometric work below we use weekly data. Thus, a j-month eurodeposit will mature at time $\mathrm{t}+4 \mathrm{j}$, assuming, for notational simplicity, that there are exactly four weeks per month. ${ }^{5}$

The expectations theory posits that the return on the $\mathrm{j}$-month investment should equal the return on a one-month investment, rolled over $\mathrm{j}$ times, plus the term premium:

$$
\left(1+\mathrm{R}_{\mathrm{t}}^{(\mathrm{j})}\right)^{\mathrm{j}}=\theta^{(\mathrm{j})}+\prod_{\mathrm{i}=0}^{\mathrm{j}-1}\left(1+\mathrm{E}_{\mathrm{t}} \mathrm{r}_{\mathrm{t}+4 \mathrm{i}} / \mathrm{j}\right) .
$$

Linearising, we have (approximately)

$$
\mathrm{R}_{\mathrm{t}}^{(\mathrm{j})} \approx \theta^{(\mathrm{j})}+\sum_{\mathrm{i}=0}^{\mathrm{j}-1}\left(\mathrm{E}_{\mathrm{t}} \mathrm{r}_{\mathrm{t}+4 \mathrm{i}} / \mathrm{j}\right)
$$

or

$$
\left(\mathrm{E}_{\mathrm{t}} \mathrm{r}_{\mathrm{t}+4(\mathrm{j}-1)}+\mathrm{E}_{\mathrm{t}} \mathrm{r}_{\mathrm{t}+4(\mathrm{j}-2)}+\ldots+\mathrm{r}_{\mathrm{t}}\right) / \mathrm{j} \approx-\theta_{\mathrm{t}}^{(\mathrm{j})}+\mathrm{R}_{\mathrm{t}}^{(\mathrm{j})} .
$$

Equation (3) spells out one implication of the EH that is the focus of the present paper: the expected return on rolling over the one-month position (on the LHS) should equal the return on holding the j-month investment until maturity, adjusted for the term premium (on the RHS). ${ }^{6}$ This implication of the $\mathrm{EH}$ can be tested by estimating

$$
r s_{t}^{(j)}=\alpha+\beta\left(R_{t}^{(j)}-r_{t}\right)+v_{t}
$$

where $\mathrm{rs}_{\mathrm{t}}^{(\mathrm{j})} \equiv \sum_{\mathrm{i}=0}^{\mathrm{j}-1}\left(\mathrm{r}_{\mathrm{t}+4 \mathrm{i}}-\mathrm{r}_{\mathrm{t}}\right) / \mathrm{j}$. Under the EH, we have $\alpha=-\theta^{(\mathrm{j})}, \mathrm{v}_{\mathrm{t}} \equiv \sum_{\mathrm{i}=0}^{\mathrm{j}-1}\left(\mathrm{r}_{\mathrm{t}+4 \mathrm{i}}-\mathrm{E}_{\mathrm{t}} \mathrm{r}_{\mathrm{t}+4 \mathrm{i}}\right) / \mathrm{j}$, and $\beta=1$. Thus, the term spread should predict a weighted average of the future change in one-month interest rates during the holding period. In what follows we refer to the LHS of equation (4) as the rollover spread, $\mathrm{rs}_{\mathrm{t}}^{(\mathrm{j})}{ }^{7}$ Note that although we, as others, assume that expectation errors, $\mathrm{r}_{\mathrm{t}+\mathrm{i}}-\mathrm{E}_{\mathrm{t}} \mathrm{r}_{\mathrm{t}+\mathrm{i}}$, are

5 In estimation, we assume that there are 13, 26 and 52 weeks when j equals 3, 6 and 12. See also footnote 8.

6 Another testable implication of the EH is that an upward-sloping yield curve should predict rising long interest rates (see Hardouvelis (1994)). This implication, however, is typically not tested in research focusing on the short end of the yield curve.

7 In what follows, when we discuss the predictability of short-term interest rates, we mean, strictly speaking, the predictability of the rollover spread. 
uncorrelated over time, $\mathrm{v}_{\mathrm{t}}$ is not white noise. If the observations are weekly, the errors obey an $\operatorname{MA}(4 \mathrm{j}-1)$ process. ${ }^{8}$

\section{Econometric results}

Next we estimate equation (4) using weekly euromarket data for ten currencies from 14th March 1979 to 7 th August $1996 .{ }^{9}$ The start of the estimation period reflects the adoption of the exchange rate mechanism (ERM) within the EMS. We use eurorates for two reasons. First, eurorates are less affected than onshore rates by capital controls, tax considerations or legal regulations, which could drive observed rates away from equilibrium levels. Secondly, the rates for different currencies are directly comparable and do not depend on factors such as default risk, differences in duration, the calculation of yields, etc.

\subsection{Full-sample results}

Before turning to the econometric results, it is informative to consider Figure 1, which contains scatter plots of the rollover spread, $r_{t}^{(j)}$, against the term spread, $\left(R_{t}^{(j)}-r_{t}\right)$. To enhance comparability, the scale on both axes is $\pm 10 \%$ for all scatter plots. ${ }^{10}$ For space reasons we only consider the case of $\mathrm{j}=6$.

To see what the EH implies for the scatter plots, assume that there are no expectation errors and that the term premium is constant. If that is the case, the data points should lie on a line that has a slope of unity and cuts the vertical axis at $-\theta^{(\mathrm{j})}$. Expectation errors would cause the data points to scatter around this line, but should not lead us to reject the hypothesis of a slope of unity. As discussed below, a time-varying term premium could bias the estimated slope of the regression line away from unity.

Consider first the scatter plot for Germany. The data points all fall relatively close to the origin, and there is little visual evidence that a fitted line would have a slope of unity. However, inspection of the scatter plots for the other countries suggests that the data for Germany are somewhat unusual, as the other countries show much more variation in both the term and rollover spreads. Furthermore, and more importantly, in France, Italy and Sweden a considerable fraction of the data

8 We therefore follow Newey and West (1987) and use standard errors that are heteroscedasticity-consistent and robust to MA errors. Since there are not exactly four weeks per month, we allow for MA errors of order 12/25/51 when the long rate is $3 / 6 / 12$ months.

9 The data stem from the BIS database, and are bid rates recorded at about 10 a.m. on the Wednesday of each week.

10 For France, Italy and the United Kingdom, in a number of cases either the term spread or the rollover spread is larger than $10 \%$ in absolute value. These observations have been dropped from the scatter plots. In Section 3.2 below we explore whether tests of the $\mathrm{EH}$ are sensitive to the presence of outliers. 
Figure 1

Rollover spreads versus term spreads $(j=6$ months)

BELGIUM

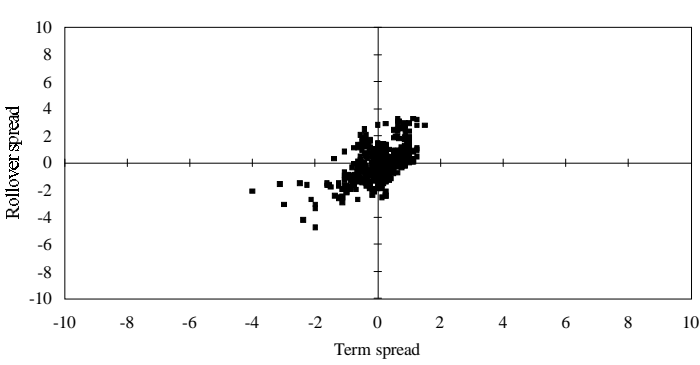

FRANCE

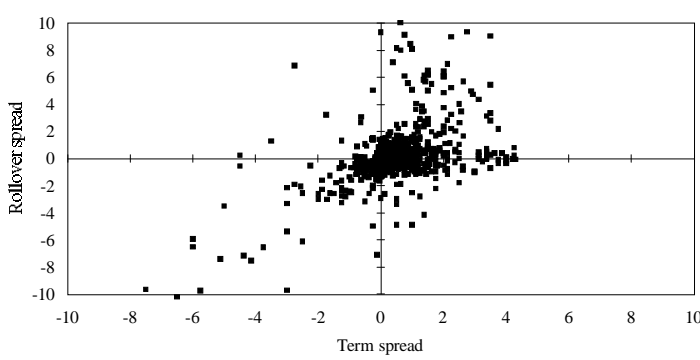

ITALY

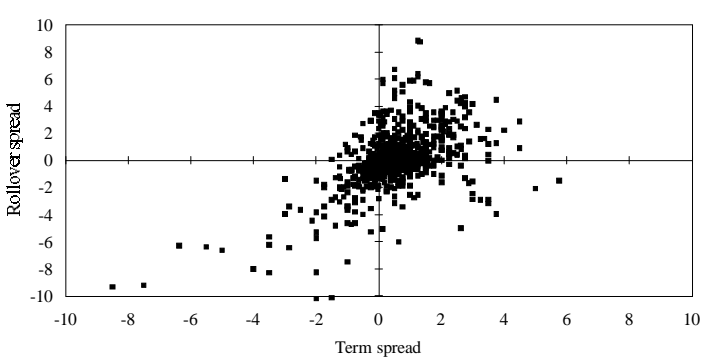

NETHERLANDS

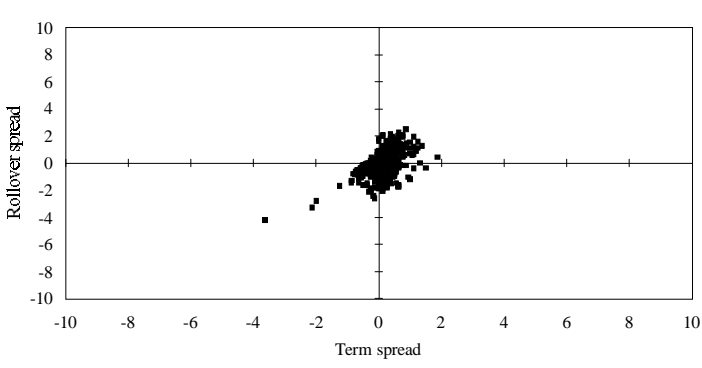

UNITED KINGDOM

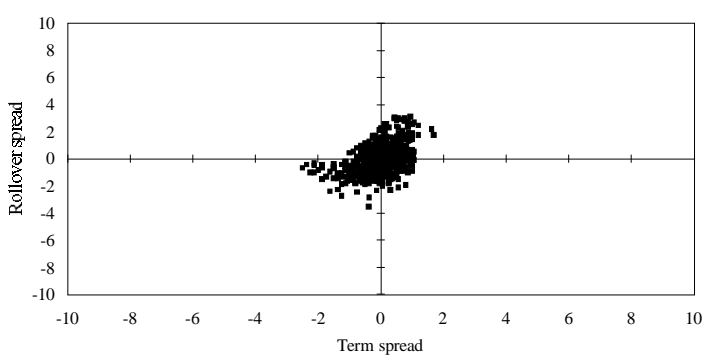

CANADA

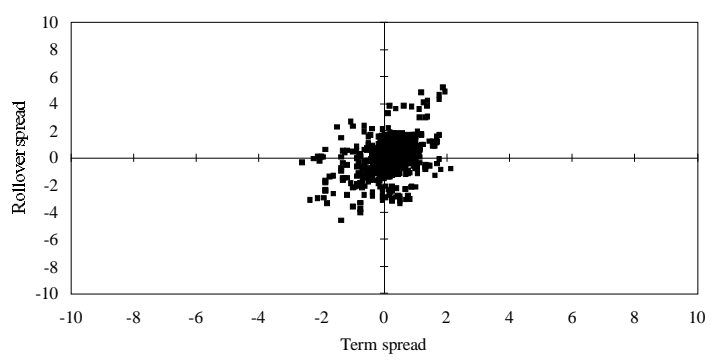

GERMANY

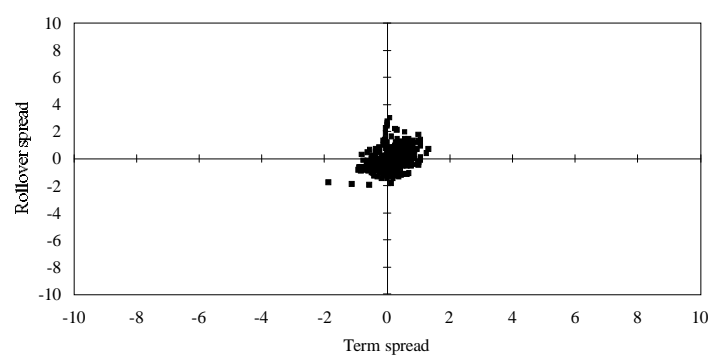

JAPAN

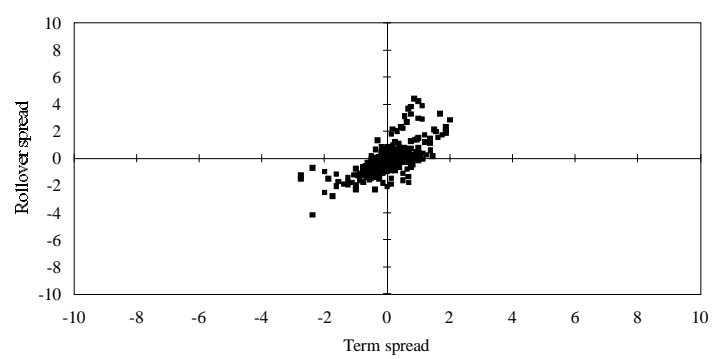

SWEDEN

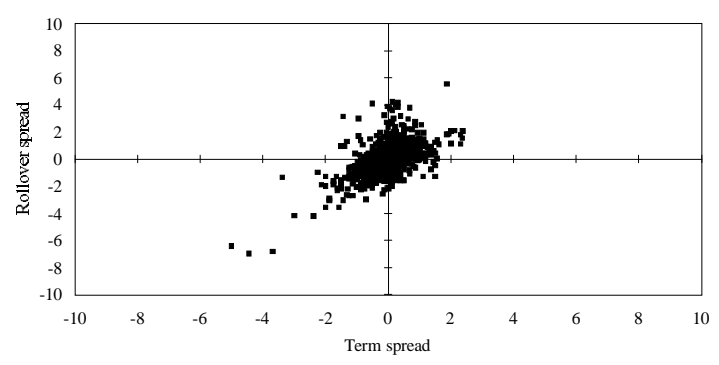

UNITED STATES

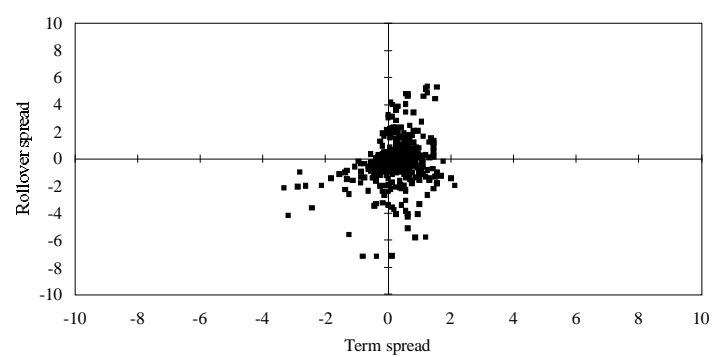


points tends to fall in the lower left-hand and the upper right-hand quadrants, leading to a visual impression of a 45 degree line. These data points are likely to reflect exchange market turmoil.

To see this, suppose that the domestic exchange rate is subject to pressures in the foreign exchange market. To stem the outflows, the central bank raises domestic short-term interest rates. Since market participants realise that this measure is likely to be temporary, longer-term interest rates rise by less than short-term rates, that is, $R_{t}^{(j)}-r_{t}<0$. Since the central bank will reduce short-term interest rates after some time - either because the costs of defending the currency grow too high or because the exchange market pressures subside - future short-term interest rates will be falling, that is,

Table 1

\section{Full-sample estimates}

\begin{tabular}{|c|c|c|c|c|c|}
\hline \multirow[t]{2}{*}{ Countries } & \multirow[t]{2}{*}{$\begin{array}{c}\text { Maturity } \\
\text { in months } \\
(\mathbf{j})\end{array}$} & \multirow[t]{2}{*}{ Observations $^{1}$} & \multicolumn{2}{|c|}{$\begin{array}{c}\text { Parameter estimates }^{2} \\
\text { (p-values for test of } \alpha=0 \text { and } \\
\beta=0, \text { in } \%)\end{array}$} & \multirow[t]{2}{*}{$\begin{array}{c}\text { p-values for test } \\
\text { of } \beta=1 \\
\text { (in \%) }\end{array}$} \\
\hline & & & $\alpha$ & $\beta$ & \\
\hline \multicolumn{6}{|c|}{ Floating exchange rates } \\
\hline Canada & $\begin{array}{c}3 \\
6 \\
12\end{array}$ & $\begin{array}{l}906 \\
893 \\
867\end{array}$ & $\begin{array}{c}-0.13 \\
(1.1) \\
-0.22 \\
(13.5) \\
-0.33 \\
(27.9) \\
\end{array}$ & $\begin{array}{c}0.86 \\
(0.0) \\
0.72 \\
(0.1) \\
0.62 \\
(0.0) \\
\end{array}$ & $\begin{array}{r}32.9 \\
18.6 \\
1.2\end{array}$ \\
\hline Germany & $\begin{array}{c}3 \\
6 \\
12\end{array}$ & $\begin{array}{l}906 \\
893 \\
867\end{array}$ & $\begin{array}{c}-0.06 \\
(0.9) \\
-0.11 \\
(13.4) \\
-0.18 \\
(35.0) \\
\end{array}$ & $\begin{array}{l}0.67 \\
(0.0) \\
0.65 \\
(0.0) \\
0.71 \\
(0.1) \\
\end{array}$ & $\begin{array}{c}0.1 \\
0.5 \\
17.7\end{array}$ \\
\hline Japan & $\begin{array}{c}3 \\
6 \\
12\end{array}$ & $\begin{array}{l}906 \\
893 \\
867\end{array}$ & $\begin{array}{c}-0.07 \\
(0.2) \\
-0.09 \\
(14.8) \\
-0.14 \\
(38.0)\end{array}$ & $\begin{array}{c}0.75 \\
(0.0) \\
1.04 \\
(0.0) \\
1.24 \\
(0.0) \\
\end{array}$ & $\begin{array}{c}7.0 \\
80.8 \\
21.6\end{array}$ \\
\hline $\begin{array}{l}\text { United } \\
\text { Kingdom }\end{array}$ & $\begin{array}{c}3 \\
6 \\
12\end{array}$ & $\begin{array}{l}906 \\
893 \\
867\end{array}$ & $\begin{array}{c}-0.05 \\
(13.9) \\
-0.06 \\
(57.2) \\
-0.11 \\
(60.3) \\
\end{array}$ & $\begin{array}{c}0.76 \\
(0.0) \\
0.76 \\
(0.0) \\
0.79 \\
(0.0) \\
\end{array}$ & $\begin{array}{r}6.3 \\
7.7 \\
16.0\end{array}$ \\
\hline United States & $\begin{array}{r}3 \\
6 \\
12\end{array}$ & $\begin{array}{l}906 \\
893 \\
867\end{array}$ & $\begin{array}{c}-0.09 \\
(5.9) \\
-0.22 \\
(3.8) \\
-0.36 \\
(12.0) \\
\end{array}$ & $\begin{array}{c}0.45 \\
(10.0) \\
0.64 \\
(1.6) \\
0.55 \\
(0.3) \\
\end{array}$ & $\begin{array}{r}4.8 \\
17.4 \\
1.4\end{array}$ \\
\hline
\end{tabular}


Table 1 (cont.)

\begin{tabular}{|c|c|c|c|c|c|}
\hline \multirow[t]{2}{*}{ Countries } & \multirow[t]{2}{*}{$\begin{array}{c}\text { Maturity } \\
\text { in months } \\
(\mathbf{j})\end{array}$} & \multirow[t]{2}{*}{ Observations 1} & \multicolumn{2}{|c|}{$\begin{array}{c}\text { Parameter estimates }^{2} \\
\text { (p-values for test of } \alpha=0 \text { and } \\
\beta=0 \text {, in } \% \text { ) }\end{array}$} & \multirow[t]{2}{*}{$\begin{array}{c}\text { p-values for test } \\
\text { of } \beta=1 \\
\text { (in } \% \text { ) }\end{array}$} \\
\hline & & & $\beta$ & & \\
\hline \multicolumn{6}{|c|}{ Pegged exchange rates } \\
\hline Belgium & $\begin{array}{c}3 \\
6 \\
12\end{array}$ & $\begin{array}{l}906 \\
893 \\
867\end{array}$ & $\begin{array}{c}-0.11 \\
(5.1) \\
-0.14 \\
(18.8) \\
-0.21 \\
(29.8) \\
\end{array}$ & $\begin{array}{l}0.84 \\
(0.2) \\
0.98 \\
(0.0) \\
0.85 \\
(0.0) \\
\end{array}$ & $\begin{array}{l}54.6 \\
93.4 \\
38.4\end{array}$ \\
\hline France & $\begin{array}{r}3 \\
6 \\
6\end{array}$ & $\begin{array}{l}906 \\
893 \\
867\end{array}$ & $\begin{array}{c}-0.18 \\
(8.5) \\
-0.32 \\
(9.2) \\
-0.36 \\
(28.2) \\
\end{array}$ & $\begin{array}{l}1.07 \\
(0.0) \\
1.04 \\
(0.0) \\
0.97 \\
(0.0) \\
\end{array}$ & $\begin{array}{l}12.1 \\
44.5 \\
67.3\end{array}$ \\
\hline Italy & $\begin{array}{r}3 \\
6 \\
6\end{array}$ & $\begin{array}{l}906 \\
893 \\
867\end{array}$ & $\begin{array}{l}-0.25 \\
(1.6) \\
-0.46 \\
(0.5) \\
-0.54 \\
(3.0) \\
\end{array}$ & $\begin{array}{l}0.90 \\
(0.0) \\
1.07 \\
(0.0) \\
1.13 \\
(0.0) \\
\end{array}$ & $\begin{array}{r}48.1 \\
54.4 \\
15.9\end{array}$ \\
\hline Netherlands & $\begin{array}{c}3 \\
6 \\
12\end{array}$ & $\begin{array}{l}906 \\
893 \\
867\end{array}$ & $\begin{array}{l}-0.08 \\
(0.4) \\
-0.15 \\
(2.7) \\
-0.29 \\
(7.4) \\
\end{array}$ & $\begin{array}{l}0.96 \\
(0.0) \\
0.95 \\
(0.0) \\
0.99 \\
(0.0) \\
\end{array}$ & $\begin{array}{r}88.1 \\
74.5 \\
96.8\end{array}$ \\
\hline Sweden & $\begin{array}{c}3 \\
6 \\
12\end{array}$ & $\begin{array}{l}906 \\
893 \\
867\end{array}$ & $\begin{array}{c}-0.07 \\
(23.3) \\
0.01 \\
(92.4) \\
0.10 \\
(63.4)\end{array}$ & $\begin{array}{l}1.04 \\
(0.0) \\
1.10 \\
(0.0) \\
1.03 \\
(0.0)\end{array}$ & $\begin{array}{r}60.4 \\
19.7 \\
80.3\end{array}$ \\
\hline
\end{tabular}

$\mathrm{rs}_{\mathrm{t}}^{(\mathrm{j})} \equiv \sum_{\mathrm{i}=1}^{\mathrm{j}}\left(\mathrm{r}_{\mathrm{t}+4(\mathrm{i}-1)}-\mathrm{r}_{\mathrm{t}}\right) / \mathrm{j}<0$. Thus, speculative attacks will generate observations in the lower left-hand quadrant in the scatter plots in Figure 1.

Table 1 provides estimates of the parameters in equation (4) together with the estimated standard errors and the $p$-values for the hypotheses that $\beta=0$ and $\beta=1$. Note, first, that in all cases $\beta$ is estimated to be positive and significantly different from zero at the 5\% confidence level (except the case in which $\mathrm{j}=3$ for the United States, for which the $\mathrm{p}$-value is $10 \%)$. Thus, there is evidence that 
the term spread contains information about the future path of one-month interest rates. ${ }^{11}$ The estimates vary considerably across countries however. The smallest estimates are obtained for the United States $(0.45,0.64$ and 0.55 for $\mathrm{j}=3,6$ and 12), followed by Germany, the United Kingdom and Canada. For this group of countries we can reject the hypothesis that $\beta=1$ at the $10 \%$ confidence level for at least one maturity. The largest estimates are obtained for France (1.07, 1.04 and 0.97), Italy (0.90, 1.07 and 1.13) and Sweden $(1.04,1.10$ and 1.03). While the estimates for Japan for the case $\mathrm{j}=3$ are moderate and the p-value for a test of a parameter of unity is about $7 \%$, the estimates for $j=6$ and 12 are high (1.04 and 1.24).

The results in Table 1 suggest two conclusions. First, as discussed in Gerlach and Smets (1997), it is more difficult to reject the EH in countries that have conducted monetary policy using fixed exchange rates than in countries in which policy is conducted under floating rates. Indeed, a simple OLS regression of all the $\beta$ estimates (reported in Table 1 ) on a constant and a dummy variable equal to one if the country operates under fixed exchange rates and zero otherwise confirms that the average $\beta$ estimate of 0.99 in the fixed exchange rate countries is significantly higher than the average estimate of 0.74 in the floating exchange rate countries (see regression 1 in Table 3). Secondly, while the estimates of $\beta$ are high in countries which have been exposed to a number of speculative attacks, the estimates for Belgium and the Netherlands, where speculative attacks have been less frequent, are also close to unity. This suggests that the occurrence of speculative attacks may be less important than the choice of exchange rate regime.

\subsection{The EH, exchange rate regimes and the predictability of future short rates}

In this section we explore whether the fact that it is more difficult to reject the $\mathrm{EH}$ in countries that conduct monetary policy with intermediate exchange rate targets can be explained by a higher predictability of short-term interest rates in those countries. To do so, we follow Fama (1984), Mankiw and Miron (1986) and many others in noting that variations in the term premium in violation of the $\mathrm{EH}$ - can bias the coefficient on the spread in equation (4). As a first step, recall from equation (4) that $\mathrm{R}_{\mathrm{t}}^{(\mathrm{j})}-\mathrm{r}_{\mathrm{t}}=\mathrm{E}_{\mathrm{t}} \mathrm{rs} \mathrm{s}_{\mathrm{t}}^{(\mathrm{j})}+\theta_{\mathrm{t}}^{(\mathrm{j})}$. If the correlation between the term premium $\theta_{\mathrm{t}}^{(\mathrm{j})}$ and the expected rollover spread, $\mathrm{E}_{\mathrm{t}} \mathrm{rs}_{\mathrm{t}}^{(\mathrm{j})}$, is denoted by $\rho$, the plim $\hat{\beta}$ is given by:

$$
\operatorname{plim} \hat{\beta}=\frac{\sigma^{2}\left(\mathrm{E}_{\mathrm{t}} \mathrm{r} \mathrm{s}_{\mathrm{t}}^{(\mathrm{j})}\right)+\rho \sigma\left(\mathrm{E}_{\mathrm{t}} \mathrm{rs} \mathrm{s}_{\mathrm{t}}^{(\mathrm{j})}\right) \sigma\left(\theta_{\mathrm{t}}^{(\mathrm{j})}\right)}{\sigma^{2}\left(\mathrm{E}_{\mathrm{t}} \mathrm{rs} \mathrm{s}_{\mathrm{t}}^{(\mathrm{j})}\right)+\sigma^{2}\left(\theta_{\mathrm{t}}^{(\mathrm{j})}\right)+2 \rho \sigma\left(\mathrm{E}_{\mathrm{t}} \mathrm{rs}_{\mathrm{t}}^{(\mathrm{j})}\right) \sigma\left(\theta_{\mathrm{t}}^{(\mathrm{j})}\right)}
$$

where $\sigma^{2}(\bullet)$ denotes variance and $\sigma(\bullet)$ standard deviation. From equation (5) it is clear that the estimate of $\beta$ converges to unity when the variance of the term premium is zero. However, if there is a time-varying term premium, the estimate will be biased and the size of the bias will depend, inter alia,

11 The fact that the slope parameter is significant in all regressions is somewhat surprising in the light of the existing literature on the EH. However, since we use weekly data, there are about 900 observations in our sample. 
on the variance of the expected rollover spread. As this variance goes to zero, the coefficient in (5) converges to zero (assuming that $\sigma^{2}\left(\theta_{\mathrm{t}}^{(\mathrm{j})}\right)>0$ ). ${ }^{12}$

In order to clarify the importance of the predictability of changes in the short-term interest rate for the estimate of the slope parameter, we divide the numerator and denominator of the right-hand side of equation (5) by $\sigma^{2}\left(\mathrm{rs}_{\mathrm{t}}^{(\mathrm{j})}\right)$, resulting in:

$$
\hat{\beta}=\frac{R^{2}+\rho R \Theta}{R^{2}+2 \rho R \Theta+\Theta^{2}},
$$

where $\mathrm{R}^{2}$ is the ratio of $\sigma^{2}\left(\mathrm{E}_{\mathrm{t}} \mathrm{rs}_{\mathrm{t}}^{(\mathrm{j})}\right)$ to $\sigma^{2}\left(\mathrm{rs}_{\mathrm{t}}^{(\mathrm{j})}\right)$, and $\Theta$ is the ratio of $\sigma^{2}\left(\theta_{\mathrm{t}}^{(\mathrm{j})}\right)$ to $\sigma^{2}\left(\mathrm{rs}_{\mathrm{t}}^{(\mathrm{j})}\right)$. The first of these ratios can be interpreted as a measure of the predictability of the rollover spread, and the second as a measure of the importance of the term spread.

To assess whether differences in the predictability of short-term rates account for the cross-country differences in the estimates of $\beta_{\mathrm{i}}$, we follow Mankiw and Miron (1986) and Gerlach and Smets (1997) and estimate a simple univariate forecasting equation comprising the current and lagged short and longer-term rates as explanatory variables. More precisely, we regress the rollover spread for each of the maturities on current and three lags of the short-term interest rate and the relevant term spread, that is

$$
\mathrm{rs}_{\mathrm{t}}^{(\mathrm{j})}=\gamma_{0}+\sum_{\mathrm{i}=0}^{3}\left(\gamma_{1 \mathrm{i}} \mathrm{r}_{\mathrm{t}-\mathrm{i}}+\gamma_{2 \mathrm{i}}\left(\mathrm{R}_{\mathrm{t}-\mathrm{i}}^{(\mathrm{j})}-\mathrm{r}_{\mathrm{t}-\mathrm{i}}\right)\right)+\varepsilon_{\mathrm{t}}^{(\mathrm{j})}
$$

As suggested above, the $\mathrm{R}^{2}$ from this regression, presented in Table 2, is a natural measure of the degree of predictability of changes in the short-term interest rate. It is noteworthy that the $\mathrm{R}^{2}$ :s are smallest in the United States, for which we obtain the lowest $\beta$ estimates. Furthermore, the $R^{2}$ :s are largest in France, Italy and Sweden, countries for which we obtain $\beta$ estimates close to unity.

Following Gerlach and Smets (1997), it is possible to investigate more formally whether there is a relationship between the estimates of $\beta$ and the predictability of the short rate in the country in question. Letting $\alpha_{1}=\rho \Theta, \alpha_{2}=\Theta^{2}$, and adding an error term allowing for estimation error in the $\beta$ estimates, we obtain from equation (6):

$$
\hat{\beta}_{\mathrm{i}}=\frac{\mathrm{R}_{\mathrm{i}}^{2}+\alpha_{1} \mathrm{R}_{\mathrm{i}}}{\mathrm{R}_{\mathrm{i}}^{2}+2 \alpha_{1} \mathrm{R}_{\mathrm{i}}+\alpha_{2}}+\xi_{\mathrm{i}}
$$

where the subscript i refers to the i:th estimate of the slope parameter. Since we have data on three term spreads for ten countries, $i=1, \ldots, 30$.

12 Note that the bias also depends on $\rho$ and that for sufficiently negative values of $\rho$ the $\beta$ estimate could be biased above one. See Mankiw and Miron (1986, p. 219). 
Table 2

\section{Predictability of the rollover spread}

Maturity in months (j)

\begin{tabular}{|lccc|}
\hline Country & $\mathbf{3}$ & $\mathbf{6}$ & $\mathbf{1 2}$ \\
\hline \multicolumn{2}{c|}{ Floating exchange rates } \\
\hline Canada & 0.23 & 0.18 & 0.16 \\
Germany & 0.18 & 0.18 & 0.20 \\
Japan & 0.34 & 0.48 & 0.48 \\
United Kingdom & 0.20 & 0.22 & 0.24 \\
United States & 0.09 & 0.13 & 0.15 \\
\hline \multicolumn{4}{c|}{ Pegged exchange rates } \\
\hline Belgium & 0.24 & 0.33 & 0.27 \\
France & 0.65 & 0.71 & 0.74 \\
Italy & 0.35 & 0.51 & 0.64 \\
Netherlands & 0.23 & 0.31 \\
Sweden & 0.48 & 0.58 & 0.57 \\
\hline Note: The predictability of the rollover spread is given by the $\mathrm{R}^{2}$ from equation (7). The sample periods are the same as in Table 1. \\
\hline
\end{tabular}

Equation (8) involves the $\beta_{\mathrm{i}}$ :s estimated in Section 2.1 (tabulated in Table 1), and the $\mathrm{R}_{\mathrm{i}}^{2}: \mathrm{s}$ in the regressions used to calculate the variance of the expected rollover spread (provided in Table 2). Thus, by fitting this equation we can use the resulting $\hat{\alpha}_{1}$ and $\hat{\alpha}_{2}$ to compute $\hat{\rho}$. Of course, in interpreting these estimates, it should be recalled that the underlying assumption that $\Theta$ and $\rho$ are constant across countries and maturities may not be true. Furthermore, since both the dependent and independent variables in this regression stem from first-step regressions and may be subject to estimation error, our estimates of equation (8) are subject to generated regressor bias of unknown magnitude. For these reasons, the empirical results discussed below must be treated with caution.

Table 3 reports estimates of equation (8) using non-linear least squares (regression 2). The results are quite striking: more than $80 \%$ of the cross-country and cross-maturity variation in $\beta$ estimates can be explained by differences in the predictability of the short rate. The implied estimates of the correlation between the term premium and the expected rollover spread is -0.51 , while the estimate of the ratio of the variance of the term premium to the variance of the rollover spread is 0.11 . These results are very similar to those reported in Gerlach and Smets (1997), who use monthly data from 17 countries and different sample periods. The results from the regression are illustrated in Figure 2, which contains a scatter plot of the 30 estimates of $\beta_{i}$ against the predictability of the rollover spread, together with our estimates of the non-linear relationship.

Regression 3 in Table 3 also shows that once one controls for differences in predictability, the dummy variable which captures the exchange rate regime is no longer significant. 
Table 3

\section{Estimates of:}

$$
\hat{\beta}_{\mathrm{i}}=\frac{\mathrm{R}_{\mathrm{i}}^{2}+\alpha_{1} \mathrm{R}_{\mathrm{i}}}{\mathrm{R}_{\mathrm{i}}^{2}+2 \alpha_{1} \mathrm{R}_{\mathrm{i}}+\alpha_{2}}+\alpha_{3} \mathrm{D}_{\mathrm{i}}+\alpha_{4}+\xi_{\mathrm{i}}
$$

\begin{tabular}{|c|c|c|c|c|c|}
\hline Regression & $\alpha_{1}$ & $\alpha_{2}$ & $\alpha_{3}$ & $\alpha_{4}$ & Adjusted $\mathbf{R}^{2}$ \\
\hline 1 & - & - & $\begin{array}{c}0.24 \\
(4.59)\end{array}$ & $\begin{array}{c}0.74 \\
(19.53)\end{array}$ & 0.40 \\
\hline 2 & $\begin{array}{c}-0.17 \\
(-10.45)\end{array}$ & $\begin{array}{c}0.11 \\
(15.40)\end{array}$ & - & - & 0.81 \\
\hline 3 & $\begin{array}{c}-0.13 \\
(-3.47)\end{array}$ & $\begin{array}{c}0.13 \\
(3.97)\end{array}$ & $\begin{array}{c}0.03 \\
(0.99)\end{array}$ & $\begin{array}{c}0.09 \\
(0.83)\end{array}$ & 0.82 \\
\hline
\end{tabular}

This confirms that the higher $\beta$ estimates in countries with pegged exchange rates can be explained by the higher predictability of short-term interest rates in these countries. Indeed, Figure 2 shows that, with the exception of Japan, the $\mathrm{R}^{2}$ :s for countries with floating exchange rates are almost uniformly lower than those for countries with fixed exchange rates. We view Table 3 and Figure 2 as presenting compelling evidence that international differences in the predictability of short-term interest rates, coupled with time-varying risk premia, account for differences between countries in the estimates of $\beta_{\mathrm{i}}$. Furthermore, the inability to reject the EH by this test in countries with pegged exchange rates is due to the higher predictability of short-term rates in these countries.

Figure 2

\section{Slope parameters versus the predictability of the short rate}

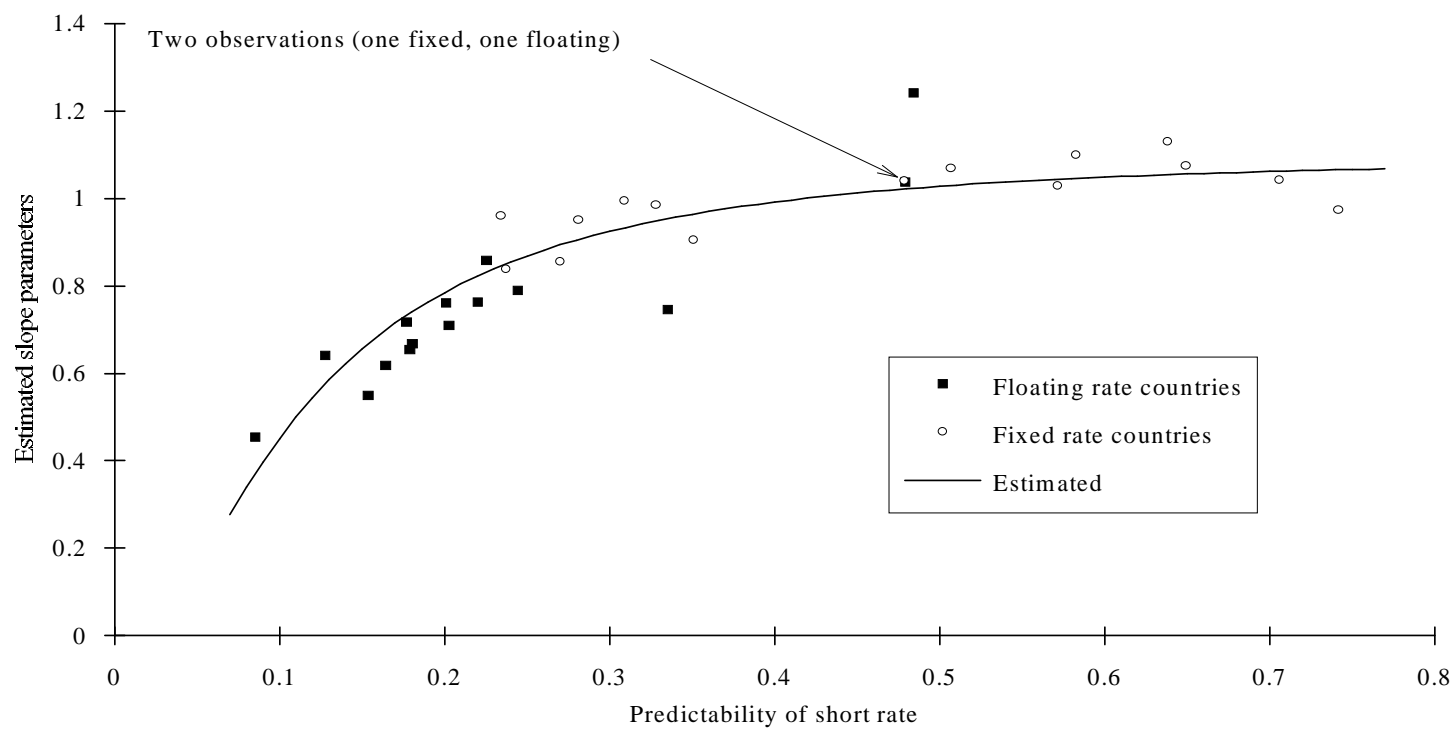


The latter finding raises the question of whether this higher predictability is attributable to occasional episodes of speculative attacks in the foreign exchange market. In the next section we investigate this issue.

\section{The EH and exchange market turmoil}

In this section we examine the stability of the results reported in the section above by considering two subsamples corresponding to periods of exchange market turmoil and periods of tranquillity. The goal of the analysis is to examine whether the reason why the $\mathrm{EH}$ works better in countries operating under fixed exchange rates is to be found in occasional periods of speculative pressures in the foreign exchange market. To this end, we estimate the following modified version of equation (4):

$$
\mathrm{rs}_{\mathrm{t}}^{(\mathrm{j})}=\left(1-\mathrm{D}_{\mathrm{t}}\right) \times\left\{\alpha^{\mathrm{NA}}+\beta^{\mathrm{NA}}\left(\mathrm{R}_{\mathrm{t}}^{(\mathrm{j})}-\mathrm{r}_{\mathrm{t}}\right)\right\}+\mathrm{D}_{\mathrm{t}} \times\left\{\alpha^{\mathrm{SA}}+\beta^{\mathrm{SA}}\left(\mathrm{R}_{\mathrm{t}}^{(\mathrm{j})}-\mathrm{r}_{\mathrm{t}}\right)\right\}+\mathrm{v}_{\mathrm{t}},
$$

where $\mathrm{D}$ is a dummy variable which takes on the value of one in periods of exchange market turmoil, SA denotes "speculative attack" and "NA" denotes "no attack". Note that it seems plausible that the variance of the error term is larger during speculative attack episodes. However, since we calculate heteroscedasticity-consistent standard errors, we do not adjust for this.

It is not self-evident how to discriminate between speculative attack and calmer periods, that is, how to define $D_{t}$. Since the results may depend on the exact way in which this is done, we use three different criteria - one economic, one statistical and one institutional - which are described in the three subsections below. For each of these criteria, Tables 4 to 6 give our estimates of $\beta^{\mathrm{NA}}$ and $\beta^{\mathrm{SA}}$, together with the p-values for tests of the hypotheses that they are equal to zero or one, and that they are equal to each other.

\subsection{Changes in interest rate spreads}

The first criterion we use to divide the sample in turbulent and calm periods is based on the fact that periods of exchange market turmoil are usually associated with large increases in domestic interest rates relative to those in the reference country, as investors need to be compensated for the expected depreciation of the domestic currency. Since speculative attacks typically last for several weeks, we define a period of exchange market turmoil as the week in which the interest rate spread increases by 100 basis points, plus the following seven weeks. ${ }^{13} \mathrm{We}$ stress that since this criterion has clear economic underpinnings, the results reported in this section are more easily interpretable than those reported in the subsequent two sections.

13 The results are not very different if, for example, the bigger point is changed from 100 basis points to 650 or the duration from eight weeks to four. 
We use German interest rates as reference rates for each of the five countries with pegged exchange rates. While, strictly speaking, no country pegged its exchange rate to the DM in the sample period, Germany played a central role for the countries participating in the ERM, as well as for Sweden.

Table 4

Estimates of equation (5), using increases in spreads between domestic and foreign one-month interest rates to identify speculative attacks

\begin{tabular}{|c|c|c|c|c|c|c|c|c|}
\hline \multirow{2}{*}{\multicolumn{2}{|c|}{$\begin{array}{l}\text { Countries } \\
\text { Maturity } \\
\text { in months }(\mathbf{j})\end{array}$}} & \multirow{3}{*}{$\begin{array}{l}\text { Observations }^{2} \\
\text { NA/SA } \\
804 / 102\end{array}$} & \multicolumn{2}{|c|}{$\begin{array}{c}\text { Parameter } \\
\text { estimates } 1 \\
\text { (p-values for test } \\
\text { of } \beta=0, \text { in } \% \text { ) }\end{array}$} & \multicolumn{4}{|c|}{ p-values for hypothesis tests (in \%) } \\
\hline & & & $\beta^{\mathrm{NA}}$ & $\beta^{\text {SA }}$ & $\beta^{\mathrm{NA}}=1$ & $\beta^{S A}=1$ & $\beta^{\mathrm{NA}}=\beta^{\mathrm{SA}}$ & $\beta^{\mathrm{NA}}=\beta=1$ \\
\hline \multirow[t]{3}{*}{ Belgium } & 3 & & $\begin{array}{l}1.06 \\
(0.0)\end{array}$ & $\begin{array}{l}0.42 \\
(6.8)\end{array}$ & 81.9 & 1.1 & 2.3 & 2.0 \\
\hline & 6 & $791 / 102$ & $\begin{array}{l}1.09 \\
(0.0)\end{array}$ & $\begin{array}{l}0.71 \\
(0.0)\end{array}$ & 68.1 & 7.8 & 10.1 & 13.3 \\
\hline & 12 & $765 / 102$ & $\begin{array}{l}0.63 \\
(0.0)\end{array}$ & $\begin{array}{l}0.63 \\
(0.0)\end{array}$ & 59.8 & 0.4 & 26.2 & 1.5 \\
\hline \multirow[t]{3}{*}{ France } & 3 & $772 / 134$ & $\begin{array}{l}0.91 \\
(0.1)\end{array}$ & $\begin{array}{c}1.08 \\
(0.0)\end{array}$ & 72.3 & 10.7 & 49.9 & 22.6 \\
\hline & 6 & $759 / 134$ & $\begin{array}{l}0.69 \\
(1.6)\end{array}$ & $\begin{array}{c}1.08 \\
(0.0)\end{array}$ & 28.6 & 0.8 & 16.2 & 0.1 \\
\hline & 12 & $733 / 134$ & $\begin{array}{l}0.59 \\
(3.0)\end{array}$ & $\begin{array}{l}1.03 \\
(0.0)\end{array}$ & 12.5 & 56.7 & 12.2 & 30.2 \\
\hline \multirow[t]{3}{*}{ Italy } & 3 & 719/187 & $\begin{array}{l}0.52 \\
(1.0)\end{array}$ & $\begin{array}{c}1.13 \\
(0.0)\end{array}$ & 1.8 & 29.1 & 0.5 & 2.0 \\
\hline & 6 & $706 / 187$ & $\begin{array}{l}0.74 \\
(0.0)\end{array}$ & $\begin{array}{l}1.20 \\
(0.0)\end{array}$ & 13.0 & 19.0 & 2.1 & 6.9 \\
\hline & 12 & $680 / 187$ & $\begin{array}{l}0.99 \\
(0.0)\end{array}$ & $\begin{array}{l}1.15 \\
(0.0)\end{array}$ & 96.3 & 10.2 & 44.9 & 18.2 \\
\hline \multirow[t]{3}{*}{ Netherlands } & 3 & $869 / 37$ & $\begin{array}{l}0.82 \\
(1.0)\end{array}$ & $\begin{array}{l}1.65 \\
(0.0)\end{array}$ & 42.9 & 0.0 & 0.0 & 0.0 \\
\hline & 6 & $856 / 37$ & $\begin{array}{l}0.74 \\
(0.0)\end{array}$ & $\begin{array}{l}1.30 \\
(0.0)\end{array}$ & 31.2 & 2.5 & 0.8 & 1.5 \\
\hline & 12 & $830 / 37$ & $\begin{array}{l}0.99 \\
(0.0)\end{array}$ & $\begin{array}{c}1.01 \\
(0.0)\end{array}$ & 68.1 & 94.7 & 66.5 & 90.0 \\
\hline \multirow[t]{3}{*}{ Sweden } & 3 & $764 / 142$ & $\begin{array}{l}0.86 \\
(0.0)\end{array}$ & $\begin{array}{l}1.10 \\
(0.0)\end{array}$ & 45.7 & 6.4 & 22.0 & 14.5 \\
\hline & 6 & $751 / 142$ & $\begin{array}{l}0.92 \\
(0.0)\end{array}$ & $\begin{array}{l}1.17 \\
(0.0)\end{array}$ & 44.4 & 0.5 & 2.6 & 1.0 \\
\hline & 12 & $725 / 142$ & $\begin{array}{l}0.74 \\
(0.0) \\
\end{array}$ & $\begin{array}{r}1.17 \\
(0.0) \\
\end{array}$ & 15.2 & 0.4 & 0.9 & 0.0 \\
\hline \multicolumn{9}{|c|}{$\begin{array}{l}\text { Note: The dummy variable equals one in the week in which the spread between domestic and foreign one-month interest rates rises by } \\
110 \text { basis points. } \\
1 \text { Newey and West (1987) standard errors, which are heteroscedasticity-consistent and robust to MA errors of order } 12,25 \text { or } 51 \\
\text { depending on the maturity of the long rate, j. }{ }^{2} \text { Estimation periods are 1979:3:12-1996:7:15 for the three-month maturity } \\
\text { 1979:3:12-1996:4:15 for the six-month maturity and 1979:3:12-1995:10:16 for the 12-month maturity. }\end{array}$} \\
\hline
\end{tabular}


In Table 4 we present the results from the estimation of equation (9). First, with the exception of Belgium, the $\beta$ estimates are higher in periods of exchange market turmoil than in calm periods. Leaving aside the case of Belgium, we find that the average $\beta$ estimate is 0.79 in calm periods - which is very close to the average $\beta$ estimate of 0.74 we found above for the countries with floating exchange rates - and 1.17 in turbulent episodes. In half of these 12 cases we can reject the hypothesis that $\beta^{\mathrm{NA}}=\beta^{\mathrm{SA}}$. Furthermore, in half of the 12 cases we can also reject that both are equal to one. Somewhat surprisingly, in the case of France we cannot reject these two hypotheses in five out of six cases, in spite of the fact that the differences in $\beta$ estimates are comparable to those in some of the other countries. Overall, this evidence suggests that including episodes of exchange market turmoil in the estimation period generally leads to higher $\beta$ estimates and can thus make it more difficult to reject the $\mathrm{EH}$ in countries which have undergone speculative attacks. In essence, speculative attacks give rise to large, but temporary, increases in the one-month interest rate which reduce the relative importance of time-varying risk premia.

However, Table 4 also shows that only in one of the 15 cases can we reject the EH $(\beta=1)$ in calm periods. This again underlines the general finding in Gerlach and Smets (1997) and in Table 1 of this paper that it is surprisingly difficult to reject the EH in countries other than the United States. Moreover, these results show that this finding cannot simply be explained by the fact that most European economies have operated monetary policy under fixed exchange rates and have experienced occasional speculative attacks.

\subsection{Outlier analysis}

In order to assess whether the results reported above depend on the criterion used to distinguish between turbulent and calm periods in the foreign exchange market, we next re-estimate the regressions reported in Table 1 and test whether the slope parameters are larger for observations that are associated with outliers. Thus, we set $\mathrm{D}=1$ for those observations for which the residuals from the regressions reported in Table 1 are more than two standard deviations in absolute value.

The results reported in Table 5 are very similar to those reported in Table 4, and do not warrant much further comment. Again we find that in 14 of the 15 cases the $\beta$ estimates are higher in periods of exchange market turmoil than in calm periods, although in many cases these differences are not statistically significant. In addition we find that, as in Section 3.1, dropping the outliers does not invalidate our previous finding that it is more difficult to reject the $\mathrm{EH}$ in these countries than in the United States, as evidenced by the fact that we reject the EH only in one out of 15 cases.

\subsection{Realignment dates}

Finally, we use information about ERM realignments to identify periods of exchange market turmoil. In this section we define as a speculative attack episode the eight weeks before and 
Table 5

Estimates of equation (5), using outliers to identify speculative attacks

\begin{tabular}{|c|c|c|c|c|c|c|c|c|}
\hline \multirow{2}{*}{\multicolumn{2}{|c|}{$\begin{array}{r}\text { Countries } \\
\text { Maturity } \\
\text { in months }(\mathbf{j}) \\
\end{array}$}} & \multirow[b]{2}{*}{$\begin{array}{c}\text { Observations }^{2} \\
\text { NA/SA }\end{array}$} & \multicolumn{2}{|c|}{$\begin{array}{c}\text { Parameter } \\
\text { estimates } 1 \\
\text { (p-values for test } \\
\text { of } \beta=0, \text { in } \%)\end{array}$} & \multicolumn{4}{|c|}{ p-values for hypothesis tests (in \%) } \\
\hline & & & $\beta^{\text {NA }}$ & $\beta^{\text {SA }}$ & $\beta^{\mathrm{NA}}=1$ & $\beta^{S A}=1$ & $\beta^{\mathrm{NA}}=\beta^{\mathrm{SA}}$ & $\beta^{\mathrm{NA}}=\beta=1$ \\
\hline \multirow[t]{3}{*}{ Belgium } & 3 & $857 / 49$ & $\begin{array}{l}0.86 \\
(0.0)\end{array}$ & $\begin{array}{l}0.89 \\
(6.7)\end{array}$ & 29.0 & 82.4 & 94.3 & 57.1 \\
\hline & 6 & $827 / 66$ & $\begin{array}{c}1.0 \\
(0.0)\end{array}$ & $\begin{array}{l}1.26 \\
(0.1)\end{array}$ & 99.9 & 50.8 & 50.2 & 79.7 \\
\hline & 12 & $824 / 43$ & $\begin{array}{l}0.84 \\
(0.0)\end{array}$ & $\begin{array}{l}1.69 \\
(0.0)\end{array}$ & 29.3 & 9.9 & 3.6 & 7.3 \\
\hline \multirow[t]{3}{*}{ France } & 3 & $861 / 45$ & $\begin{array}{l}0.99 \\
(0.0)\end{array}$ & $\begin{array}{l}2.06 \\
(0.0)\end{array}$ & 81.1 & 1.1 & 0.9 & 2.1 \\
\hline & 6 & $830 / 63$ & $\begin{array}{l}1.01 \\
(0.0)\end{array}$ & $\begin{array}{l}1.27 \\
(0.0)\end{array}$ & 76.8 & 42.5 & 42.3 & 72.5 \\
\hline & 12 & $802 / 65$ & $\begin{array}{l}0.80 \\
(0.0)\end{array}$ & $\begin{array}{l}1.07 \\
(0.0)\end{array}$ & 6.3 & 27.0 & 0.4 & 1.1 \\
\hline \multirow[t]{3}{*}{ Italy } & 3 & $844 / 62$ & $\begin{array}{l}0.87 \\
(0.0)\end{array}$ & $\begin{array}{l}1.07 \\
(1.1)\end{array}$ & 9.0 & 86.3 & 59.5 & 12.3 \\
\hline & 6 & $838 / 55$ & $\begin{array}{l}1.07 \\
(0.0)\end{array}$ & $\begin{array}{l}1.06 \\
(5.5)\end{array}$ & 28.3 & 90.8 & 99.4 & 56.1 \\
\hline & 12 & $822 / 45$ & $\begin{array}{l}1.09 \\
(0.0)\end{array}$ & $\begin{array}{l}1.30 \\
(0.0)\end{array}$ & 34.6 & 0.9 & 16.0 & 2.5 \\
\hline \multirow[t]{3}{*}{ Netherlands } & 3 & $859 / 47$ & $\begin{array}{l}0.74 \\
(0.0)\end{array}$ & $\begin{array}{l}1.74 \\
(1.2)\end{array}$ & 0.5 & 28.5 & 14.2 & 0.5 \\
\hline & 6 & $831 / 62$ & $\begin{array}{l}0.95 \\
(0.0)\end{array}$ & $\begin{array}{c}1.72 \\
(11.0)\end{array}$ & 62.3 & 50.3 & 47.0 & 67.2 \\
\hline & 12 & $796 / 71$ & $\begin{array}{l}0.98 \\
(0.0)\end{array}$ & $\begin{array}{l}1.82 \\
(3.6)\end{array}$ & 86.8 & 34.5 & 33.0 & 61.5 \\
\hline \multirow[t]{3}{*}{ Sweden } & 3 & $874 / 32$ & $\begin{array}{l}0.93 \\
(0.0)\end{array}$ & $\begin{array}{l}1.31 \\
(0.0)\end{array}$ & 38.3 & 1.9 & 0.0 & 0.1 \\
\hline & 6 & $848 / 45$ & $\begin{array}{l}1.06 \\
(0.0)\end{array}$ & $\begin{array}{l}1.43 \\
(0.0)\end{array}$ & 20.2 & 6.8 & 9.6 & 16.0 \\
\hline & 12 & $817 / 50$ & $\begin{array}{l}1.01 \\
(0.0) \\
\end{array}$ & $\begin{array}{r}1.33 \\
(0.0) \\
\end{array}$ & 89.5 & 2.0 & 2.3 & 4.7 \\
\hline \multicolumn{9}{|c|}{$\begin{array}{l}\text { Note: The dummy variable equals one for those observations in the regressions in Table } 1 \text { for which the residuals are larger than two } \\
\text { standard deviations in absolute value. } \\
1 \text { Newey and West (1987) standard errors, which are heteroscedasticity-consistent and robust to MA errors of order } 12,25 \text { or } 51 \\
\text { depending on the maturity of the long rate. }{ }^{2} \text { Estimation periods are 1979:3:12-1996:7:15 for the three-month maturity }\end{array}$} \\
\hline
\end{tabular}

two weeks after an ERM realignment. ${ }^{14}$ While this criterion suffers from the shortcoming that it will not capture periods of exchange market turmoil which did not give rise to a realignment, it provides a useful way of testing the robustness of our results.

14 The realignment dates are from Svensson (1993). We used realignment dates from the BIS database to extend the sample period beyond Svensson's sample. The results are not very sensitive to alternative assumptions regarding the duration of the episode. 
Table 6

Estimates of equation (5), using dummies corresponding to ERM events

to identify speculative attacks

\begin{tabular}{|c|c|c|c|c|c|c|c|c|}
\hline \multirow{2}{*}{\multicolumn{2}{|c|}{$\begin{array}{l}\text { Countries } \\
\qquad \text { Maturity } \\
\text { in months }(\mathbf{j})\end{array}$}} & \multirow[b]{2}{*}{$\begin{array}{c}\text { Observations }^{2} \\
\text { NA/SA }\end{array}$} & \multicolumn{2}{|c|}{ 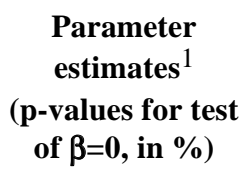 } & \multicolumn{4}{|c|}{ p-values for hypothesis tests (in \%) } \\
\hline & & & $\beta^{\text {NA }}$ & $\beta^{\mathbf{S A}}$ & $\beta^{\mathrm{NA}}=1$ & $\beta^{\mathrm{SA}}=1$ & $\beta^{\mathrm{NA}}=\beta^{\mathrm{SA}}$ & $\beta^{\mathbf{N A}}=\beta=1$ \\
\hline \multicolumn{9}{|c|}{ French and Italian ERM events ${ }^{3}$} \\
\hline \multirow[t]{3}{*}{ France } & & & $\begin{array}{l}0.84 \\
(0.9)\end{array}$ & $\begin{array}{l}1.08 \\
(0.0)\end{array}$ & 61.0 & 11.3 & 46.0 & 27.1 \\
\hline & 6 & $791 / 102$ & $\begin{array}{l}0.74 \\
(0.1)\end{array}$ & $\begin{array}{l}1.08 \\
(0.0)\end{array}$ & 14.7 & 22.2 & 12.0 & 14.5 \\
\hline & 12 & $765 / 102$ & $\begin{array}{l}0.70 \\
(0.0)\end{array}$ & $\begin{array}{l}1.05 \\
(0.0)\end{array}$ & 9.7 & 0.0 & 5.1 & 0.0 \\
\hline \multirow[t]{3}{*}{ Italy } & 3 & $736 / 170$ & $\begin{array}{l}0.75 \\
(0.0)\end{array}$ & $\begin{array}{l}1.20 \\
(0.0)\end{array}$ & 17.8 & 1.3 & 2.5 & 1.7 \\
\hline & 6 & $723 / 170$ & $\begin{array}{l}0.88 \\
(0.0)\end{array}$ & $\begin{array}{l}1.47 \\
(0.0)\end{array}$ & 36.9 & 0.4 & 1.3 & 1.4 \\
\hline & 12 & $697 / 170$ & $\begin{array}{l}0.98 \\
(0.0) \\
\end{array}$ & $\begin{array}{l}1.43 \\
(0.0) \\
\end{array}$ & 88.4 & 0.4 & 1.1 & 1.4 \\
\hline \multicolumn{9}{|c|}{ General ERM events ${ }^{4}$} \\
\hline \multirow[t]{3}{*}{ France } & 3 & & $\begin{array}{l}0.86 \\
(7.2)\end{array}$ & $\begin{array}{l}1.09 \\
(0.0)\end{array}$ & 77.3 & 4.7 & 63.4 & 13.9 \\
\hline & 6 & $618 / 275$ & $\begin{array}{l}0.49 \\
(5.4)\end{array}$ & $\begin{array}{l}1.12 \\
(0.0)\end{array}$ & 4.7 & 9.0 & 2.5 & 6.1 \\
\hline & 12 & $592 / 275$ & $\begin{array}{c}0.5 \\
(2.0)\end{array}$ & $\begin{array}{l}1.07 \\
(0.0)\end{array}$ & 2.7 & 1.2 & 1.0 & 0.2 \\
\hline \multirow[t]{3}{*}{ Italy } & 3 & $631 / 275$ & $\begin{array}{l}0.65 \\
(0.5)\end{array}$ & $\begin{array}{l}1.14 \\
(0.0)\end{array}$ & 12.4 & 4.4 & 4.0 & 4.2 \\
\hline & 6 & $618 / 275$ & $\begin{array}{l}0.79 \\
(0.0)\end{array}$ & $\begin{array}{l}1.36 \\
(0.0)\end{array}$ & 22.1 & 0.3 & 1.4 & 1.1 \\
\hline & 12 & $592 / 275$ & $\begin{array}{l}0.96 \\
(0.0) \\
\end{array}$ & $\begin{array}{l}1.33 \\
(0.0) \\
\end{array}$ & 78.3 & 1.3 & 5.5 & 4.3 \\
\hline \multicolumn{9}{|c|}{$\begin{array}{l}1 \text { Newey and West (1987) standard errors, which are heteroscedasticity-consistent and robust to MA errors of order } 12,25 \text { or } 51 \text {, } \\
\text { depending on the maturity of the long rate, j. }{ }^{2} \text { Estimation periods are 1979:3:12-1996:7:15 for the three-month maturity, } \\
\text { 1979:3:12-1996:4:15 for the six-month maturity and 1979:3:12-1995:10:16 for the 12-month maturity. }{ }^{3} \text { The dummies pertain to the } \\
\text { week in which an ERM realignment of the French franc vis-à-vis the Italian lira occurred (plus the eight weeks before and after), the } \\
\text { abandonment of ERM parity of the lira in September } 1992 \text { and the broadening of the ERM bands in August } 1993 .{ }^{4} \text { The dummies } \\
\text { pertain to the week in which an ERM realignment occurred (plus the eight weeks before and after), the abandonment of the ERM parity } \\
\text { of the lira in September } 1992 \text { and the broadening of the ERM bands in August 1993. }\end{array}$} \\
\hline
\end{tabular}

Before turning to the results, it should be noted that the fact that this criterion only classifies as speculative attacks episodes that led to changes in the parity has implications for the likely size of the slope parameter. Since central banks are likely to cut interest rates faster after 
speculative attacks that result in realignments than after those that do not, the estimates of $\beta^{\mathrm{SA}}$ may well be larger than unity.

The results in Table 6 are quite interesting. Note that the estimates of $\beta^{\mathrm{NA}}$ are less than unity (but typically not significantly so), while the estimates of $\beta^{\mathrm{SA}}$ tend to be larger than unity, and in most cases significantly so. Thus, these results also suggest that the EH works "better" (in the sense that the estimate of the slope parameter is larger) if episodes of speculative attacks are included in the sample. However, since we are unable to reject the hypothesis that $\beta=1$ in periods without such attacks, it is clear that monetary policy reactions to speculative pressures on the exchange rate are not the sole reason why the EH fares better in European data.

\section{Conclusions}

The main findings in the paper can be summarised as follows. First, there is considerable evidence that it is more difficult to reject the $\mathrm{EH}$ of the term structure in countries in which monetary policy is conducted using intermediate exchange rate targets than in countries where no such targets are used. Secondly, short-term interest rates are more predictable in countries with such exchange rate objectives. Thirdly, the occurrence of occasional speculative attacks is one reason why it may be more difficult to reject the EH under fixed exchange rates, but it is not the only one. Even restricting the sample period to calm periods, we still fail to reject the EH in countries with exchange rate objectives.

The fact that differences in the predictability of short-term interest rates matter for the test of the EH considered here suggests that time-varying term premia may be present. In floating exchange rate countries where short-term rates are relatively difficult to forecast, the time variation of the term premium drives $\beta$ sufficiently far away from unity for us to reject the EH. By contrast, in fixed exchange rate countries where short-term rates are easier to predict, estimates of $\beta$ are dominated by expected changes of the short rate and we are therefore unable to reject the EH. 


\section{References}

Dahlquist, Magnus and Gunnar Jonsson (1995): "The information in Swedish short-maturity forward rates". European Economic Review, June, 39:1115-32.

Gerlach, Stefan (1996): "Monetary policy and the behaviour of interest rates: Are long rates excessively volatile?" BIS Working Paper, No. 34.

Gerlach, Stefan and Frank Smets (1997): "The term structure of euro-rates: some evidence in support of the EH". Journal of International Money and Finance, April, 16: 305-321.

Hardouvelis, Gikas A. (1988): "The predictive power of the term structure during recent monetary regimes". Journal of Finance, June, 43: 339-56.

Hardouvelis, Gikas A. (1994): "The term structure spread and future changes in long and short rates in the G-7 countries: Is there a puzzle?" Journal of Monetary Economics, April, 33: 255-83.

Kugler, Peter (1988): "An empirical note on the term structure and the interest rate stabilization policies", Quarterly Journal of Economics, November, 103: 789-93.

Kugler, Peter, "The term structure of Euro interest rates and rational expectations". Journal of International Money and Finance, June 1990, 9: 234-44.

Jondeau, Eric and Roland Ricart (1996): "The expectations theory: tests on French, German and American euro-rates", in The determination of long-term interest rates and exchange rates and the role of expectations, BIS Conference papers Vol. 2, Basle, Switzerland.

Mankiw, N. Gregory and Jeffrey A. Miron (1986): "The changing behavior of the term structure of interest rates". Quarterly Journal of Economics, May, 101: 211-28.

Newey, Whitney K. and Kenneth D. West (1987): "A simple, positive semi-definite, heteroscedasticity and autocorrelation consistent covariance matrix". Econometrica, May, 55: 703-08.

Shiller, Robert J. (1990): "The term structure of interest rates", in Benjamin M. Friedman and Frank H. Hahn, eds., Handbook of Monetary Economics, Vol. 1, Amsterdam: North-Holland.

Shiller, Robert J., John Y. Campbell, and Kermit I. Schoenholtz (1983): "Forward rates and future policy: Interpreting the term structure of interest rates". Brookings Papers on Economic Activity, No. 1: 173-217.

Svensson, Lars E.O. (1993): "Assessing target zone credibility: Mean reversion and devaluation expectations in the ERM, 1979-1992", European Economic Review, May, 37: 763-802. 



\section{Recent BIS Working Papers}

No.

Title

The term structure of Euro-rates: some evidence in

28

August 1995

29

September 1995

30

November 1995

31

December 1995

32

December 1995

33

January 1996

34

January 1996

35

July 1996

36

August 1996

37

September 1996

38

October 1996

39

January 1997

40

March 1997

41

May 1997

42

June 1997 support of the expectations hypothesis

The information content of the term structure: evidence for Germany

Money demand stability and currency substitution in six European countries (1980-1992)

Testing the quantity theory using long-run averaged cross-country data

The anatomy of the bond market turbulence of 1994

Derivatives and asset price volatility: a test using variance ratios

Monetary policy and the behaviour of interest rates: are long rates excessively volatile?

Varieties of monetary policy operating procedures:

balancing monetary objectives with market efficiency

Estimation of speculative attack models: Mexico yet again

Does the term structure predict recessions?

The international evidence

International agreements in the area of banking and

finance: accomplishments and outstanding issues

Banking system failures in developing and transition countries: diagnosis and prediction

Monetary policy operating procedures industrial countries

The euro and European financial markets

Measuring monetary policy shocks in France, Germany and Italy: the role of the exchange rate
Author

Stefan Gerlach and Frank Smets

Stefan Gerlach

Renato Filosa

Stefan Gerlach

Claudio E.V. Borio

Robert N. McCauley

Benjamin H. Cohen

Stefan Gerlach

Joseph Bisignano

William R. Melick

Henri Bernard and Stefan Gerlach

William R. White

Patrick Honohan

Claudio E. V. Borio

Robert N. McCauley and William R. White

Frank Smets 


ISSN 1020-0959 